\title{
COMPARATIVE CHEMICAL AND BIOLOGICAL ACTIVITY OF SELECTIVE HERBAL EXTRACTS
}

\author{
IOANA HUMULESCU ${ }^{1 \#}$, MIHAELA-MAGDALENA FLUTUR ${ }^{1}$, OANA CIOANCA $^{1}{ }^{1}$, CORNELIA $^{\prime}$ \\ MIRCEA $^{1}$, SILVIA ROBU ${ }^{2 \#}$, DENISA MARIN-BATIR ${ }^{2 *}$, ADRIAN SPAC ${ }^{1}$, ANDREIA CORCIOVA $^{1}$, \\ MONICA HĂNCIANU ${ }^{1}$ \\ ${ }^{I}$ Faculty of Pharmacy, "Grigore T. Popa" University of Medicine and Pharmacy Iași, 700115 Iași, Romania \\ ${ }^{2}$ Department of Pharmaceutical Sciences, Faculty of Medicine and Pharmacy, “Dunărea de Jos" University, 800010 Galați, \\ Romania
}

*corresponding author: oana.cioanca@gmail.com

${ }^{\#}$ Authors with equal contribution.

Manuscript received: December 2020

\begin{abstract}
The imbalance of oxidative processes poses a serious threat by overproduction of free radicals and various reactive species. Therefore, polyphenol and flavonoid-rich medicinal plants represent a common trend in daily use and pharmaceutical research. Our study focused on two type of extracts that isolated flavonoid derivatives, polyphenolic acids, and iridoids from three Teucrium species endemic in Romania. The chemical evaluation by spectrophotometric and ultra-high-performance liquid chromatography techniques indicated that methanol was a better solvent than methanol/dichloromethane mixture for quercetin, luteolin, and apigenin derivatives. Caffeic acid, rosmarinic acid, and harpagide were also identified. The biological activity was assessed by antioxidant assays (2, 2-diphenyl-1-picrylhydrazyl radical scavenger, lipoxygenase, and cholinesterase's inhibition). All in all, the methanolic extracts exhibited the best antiradical and enzyme inhibitory activity, the intensity was correlated to the chemical composition. Also, T. polium followed by T. chamaedris proved to be the richest in compounds with good antioxidant activity and represent the best choices for further investigation.
\end{abstract}

\section{Rezumat}

Dezechilibrul proceselor oxidative reprezintă o amenințare serioasă prin supraproducția radicalilor liberi și a diferitelor specii reactive. Prin urmare, plantele medicinale bogate în polifenoli și flavonoide reprezintă o tendință comună în utilizarea zilnică și în cercetarea farmaceutică. Cercetarea de față s-a axat pe două tipuri de extracte care au urmărit izolarea unor derivați flavonoidici, acizi polifenolici și iridoide din trei specii de Teucrium endemice în România. Evaluarea chimică prin tehnici de cromatografie lichidă ultra-performantă și spectrofotometrie a indicat faptul că metanolul este un solvent mai bun decât amestecul metanol/diclorometan pentru derivați de cvercetol, luteolină și apigeninol. Au fost de asemenea identificați compuși precum acidul cafeic, acidul rosmarinic și harpagozida. Activitatea biologică a fost evaluată prin teste antioxidante (chelatarea radicalilor 2, 2-difenil-1-picrilhidrazil, inhibarea lipoxigenazei și a colinesterazelor). În general, extractele metanolice au prezentat cea mai bună activitate antiradicalară și inhibitoare față de enzime, intensitatea fiind corelată cu compoziția chimică. De asemenea, specia $T$. polium urmată de $T$. chamaedris s-au dovedit cele mai bogate în compuşi cu activitate antioxidantă bună și reprezintă opțiuni de viitor pentru investigații ulterioare.

Keywords: flavonoids, polyphenols, antioxidant capacity, enzyme inhibition

\section{Introduction}

Plants and especially the medicinal ones are still considered rich sources of natural compounds. Flavonoids and polyphenolic acids represent classes of compounds present throughout the plant kingdom. They are endowed with numerous biological properties such as antioxidant, anti-inflammatory, antimicrobial, etc. However, finding new natural resources remains an important goal for researchers involved in the pharmaceutical, cosmetic and food industry fields $[1,2,12]$.

The representatives of Lamiaceae family (Salvia, Lavandula, Mentha, Origanum etc.) are aromatic species, known for their flavoring properties due to essential oil $[5,13,21,25]$. Teucrium genus is not as known and investigated as other Lamiaceae representatives, but some of its variations are presently used as medicinal (Teucrium chamaedrys L., T. montanum L.) or food spices (Teucrium polium L.) in many traditional communities throughout the world (Greece, Spain, Turkey, Iran, Morocco, etc.). Their common characteristic is that they are perennial shrubs that prefer rocky and calcareous growing conditions, especially mountain forests, meadows and pastures from Europe and Anatoly [8, 9, 14, 16]. Various research groups from these areas identified the same species as rich in essential oil, phenyl-glycosides iridoids and sterols with good antibacterial, antifungal 
FARMACIA, 2021, Vol. 69, 5

and food preservative properties [1, 3, 11]. The available data suggests that different extracts from these species possess antioxidative, antimicrobial, antiviral, hepatoprotective, cytotoxic and antimutagenic effects, although the main investigated fraction was represented by the volatile oil $[24,25]$. There are still some concerns regarding $T$. polium hepatotoxicity after human use, similarly to $T$. chamaedrys neoclerodane diterpenes that induce cellular necrosis in liver and biliary duct [1].

This study encompasses a comparative analysis of these three species that are also endemic in Romania. The aim was to assess the activity of two different extract types obtained from the aerial parts of $T$. chamaedrys, T. montanum and T. polium against free radicals and various enzymes involved in pathologies with inflammatory and increased prooxidants, as well as age-related conditions.

\section{Materials and Methods}

Plant material and preparation of plant extracts

Aerial parts of each species were collected in June 2019 from the region of North-Eastern Romania from the wild flora around Horlești and Bicaz towns. The voucher specimens of T. chamaedrys, T. montanum and T. polium were confirmed [15] and deposited at the Department of Pharmacognosy, Faculty of Pharmacy, "Grigore T. Popa" University of Medicine and Pharmacy Iași, Romania. After air-drying in darkness at $25^{\circ} \mathrm{C}$, the plant parts were cut and used for the obtaining of two selective extracts. The plant material $(2.5 \mathrm{~g} / 100 \mathrm{~mL})$ was extracted either with methanol or a mixture of methanol:dichloromethane $(1: 1)$, on a water bath using heat reflux extraction procedure. The extracts were filtered and evaporated to obtain the concentrated extract samples (Table I).

Chemical evaluation of the plant extracts

Determination of total flavonoids in the plant extracts. The total flavonoid contents were determined spectrophotometrically $[9,12,13,20]$. Briefly, $0.5 \mathrm{~mL}$ of $2 \%$ solution of $\mathrm{AlCl}_{3}$ in methanol was mixed with the same volume of extract $(1 \mathrm{mg} / \mathrm{mL})$. Absorption readings at $415 \mathrm{~nm}$ were taken after $1 \mathrm{~h}$ against a blank (methanol). The total flavonoid content was determined using a standard curve with rutoside (0 $50 \mathrm{mg} / \mathrm{mL})$. Values were expressed as rutoside equivalents to $1 \mathrm{~g}$ plant extract.

Determination of total phenolics. Total phenolic compounds in the investigated extracts of Teucrium were determined with Folin-Ciocâlteu reagent [3, 4, $9,19]$ with gallic acid as a standard. Each sample was diluted to $1 \mathrm{mg} / \mathrm{mL}$. Aliquots of $0.5 \mathrm{~mL}$ of each solute extract was mixed with $2.5 \mathrm{~mL}$ of FolinCiocâlteu reagent and $2 \mathrm{~mL}$ of $\mathrm{NaHCO}_{3}(7.5 \%)$. After 15 min of staying at the $45^{\circ} \mathrm{C}$, the absorbance was measured at $765 \mathrm{~nm}$ versus the blank sample. Content of extracts phenols was expressed in terms of gallic acid equivalent (mg GA/g extract). Values were uniformly expressed as the corresponding dry weight of plant extract $(1 \mathrm{~g})$. All measures were performed in triplicate.

UPLC-PDA analysis of plant extracts. $4 \mathrm{mg}$ of each dried extracts were solubilized in $1 \mathrm{~mL}$ methanolwater mixture with a ratio of 3:1. The stock solution was filtrated and used for UHPLC (ultra-highperformance liquid chromatography) analysis. The system consisted of a Thermo UltiMate 3000 chromatograph with a quaternary pump, an autosampler, a Phenomenex Luna Omega Polar C18 column $(100 \times 150 \times 4.6 \mathrm{~mm})$, and a UV-PDA (photodiode array detector) [7, 18].

Thus, each sample was injected in an amount of 2.5 $\mu \mathrm{L}$ and eluted with a mixture of acetonitrile with $0.1 \%$ phosphoric acid (A) and phosphoric acid $1 \%$ (B) and a flow of $0.8 \mathrm{~mL} / \mathrm{min}$. The gradient elution was $0-10 \% \mathrm{~A}$ in B for $4 \mathrm{~min}, 10-15 \%$ for $4 \mathrm{~min}$, linear $4 \mathrm{~min}$, then gradient to $85 \%$ for $15 \mathrm{~min}$, and finally $10 \%$ A for the last $3 \mathrm{~min}$. Chromeleon 7.2 v.12 software was used for the integration and the calculation of each peak. Simultaneous chromatograms were registered at $245 \mathrm{~nm}, 280 \mathrm{~nm}$ and $330 \mathrm{~nm}$. Aliquots $(2-10 \mu \mathrm{L})$ of standard stock solutions (epicatechin, caffeic acid, rosmarinic acid, chlorogenic acid, ferulic acid, luteolin, apigenin, quercetin-3arabinoside, apigenin-7-O-glucoside, and luteolin7-O-glucoside) were used for calibration curves with a correlation coefficient above 0.9989 . The standard deviation was calculated at 0.02 . The limit of detection (LOD) and the limit of quantification (LOQ) of rutin and $p$-coumaric acid were calculated at $245 \mathrm{ng} / \mathrm{mL}$ and $182 \mathrm{ng} / \mathrm{mL}$, respectively. The compounds were identified based on the retention time and UV spectra comparison with the standards for a match index above 950/1000. All standards and solvents were of HPLC quality and were bought from Sigma Aldrich (Germany).

\section{Evaluation of antioxidant and enzyme inhibitory activity}

DPPH scavenger assay. The capability of selective extracts to scavenge DPPH radicals was assessed by a commonly used spectrophotometric method $[9,13$, 20, 24, 25]. The solutions of each investigated sample were prepared in methanol, diluted with DMSO and added to $1 \mathrm{~mL}$ of DPPH methanolic solution (with an initial absorbance of 1.15). After the incubation, the absorbance of the mixture was registered at $517 \mathrm{~nm}$. Inhibitory concentration of $50 \%$ of the existent radicals $\left(\mathrm{IC}_{50}\right)$ were estimated using a linear algorithm. In the presented data, the antioxidant efficiency is higher for lower $\mathrm{IC}_{50}(\mu \mathrm{g} / \mathrm{mL})$ values.

15-lipoxygenase inhibition (amended Malterud method). The bioactive substances from the selective extracts have the ability to block the activity of lipoxygenase (LOX) which catalyses the oxidation of linoleic acid, thus reducing the initial absorbance measured at 
FARMACIA, 2021, Vol. 69, 5

$234 \mathrm{~nm}$. Aliquot of $0.05 \mathrm{~mL}$ of LOX in borate buffer was mixed with $0.05 \mathrm{~mL}$ of each sample in dimethyl sulfoxide (DMSO) and left to stand for 10 minutes at room temperature, and then $2 \mathrm{~mL}$ of linoleic acid were added to these mixtures. The absorbance of each sample at $234 \mathrm{~nm}$ was registered for 2 minutes [4, 5, 7, 12, 19].

\section{Butyrylcholinesterase/Acetylcholinesterase} inhibition (Ellman's method). Acetylcholinesterase (AChE) from Electrophorus electricus or butyrylcholinesterase (BuChE) with acetylthiocholine iodide $(0.2 \mathrm{M})$ as a substrate, were used for this test. The inhibitory potential of Teucrium extracts was assessed by Ellman's method with slight changes $[5,7,13,17$, 19]. Briefly, in the reaction medium, containing the enzyme $(0.2 \mathrm{U} / \mathrm{mL}$ in phosphate buffer), $0.2 \mathrm{M}$ Ellman solution and the sample (Teucrium extracts diluted in DMSO) were added. After 15 minutes at $25^{\circ} \mathrm{C}$, the substrate was added to the mixture and the absorbance

was recorded at $412 \mathrm{~nm}$ for 300 seconds. Galantamine was used as a positive inhibitor.

All the obtained values represent the mean and standard deviation of triplicate measurements $(n=3)$.

\section{Results and Discussion}

The spreading pf the studied plantsis correlated to all literature data that indicates that Teucrium genus representatives are adapted to higher altitude habitats $[1,14,16,26]$. However, in Serbia there is a warmhumid continental influence whereas in North-East Romania the climate is dry continental. The pedoclimatic condition will impact the biosynthesis capacity of the plants.

The total flavonoids (TFC), total polyphenols (TPC) quantified in our selective extracts obtained from three Teucrium species are indicated in Table I, along with the extraction yield (g).

Table I

Extraction yields and quantification of the most important classes of compounds from T. chamaedrys, T. montanum and $T$. polium selective extracts

\begin{tabular}{|l|c|c|c|}
\hline \multicolumn{1}{|c|}{ Sample } & Extraction yield & TPC $(\boldsymbol{m g}$ GAE/g dry extract $)$ & TFC (mg GAE/g dry extract $)$ \\
\hline TCm & $1.93 \pm 0.042$ & $245.37 \pm 0.75$ & $90.27 \pm 0.25$ \\
\hline $\boldsymbol{T C m} \boldsymbol{d}$ & $0.82 \pm 0.015$ & $112.34 \pm 0.25$ & $45.13 \pm 0.03$ \\
\hline $\boldsymbol{T M m}$ & $0.97 \pm 0.023$ & $164.42 \pm 0.03$ & $51.42 \pm 0.15$ \\
\hline $\boldsymbol{T M m} \boldsymbol{d}$ & $0.78 \pm 0.041$ & $87.12 \pm 0.11$ & $20.24 \pm 0.07$ \\
\hline $\boldsymbol{T P m}$ & $1.95 \pm 0.011$ & $258.22 \pm 0.17$ & $112.40 \pm 0.25$ \\
\hline $\boldsymbol{T P m} \boldsymbol{d}$ & $0.87 \pm 0.015$ & $147.35 \pm 0.07$ & $76.14 \pm 0.08$ \\
\hline
\end{tabular}

*TCm - T. chamaedrys methanolic extract; TCmd - T. chamaedrys methanolic/dichlorometanolic extract; TMm - T. montanum methanolic extract; TMmd - T. montanum methanolic/ dichlorometanolic extract; TPm - T. polium methanolic extract; TPmd - T. polium methanolic/dichlorometanolic extract.

The best extraction yields were noted for the methanolic extracts as compared to the methanolic/dichloromethane extracts, the most significant results were given by Teucrium polium and T. chamaedris. Our results are in agreement with the comparative analysis of Stancovic et al. and Sharififar et al. which obtained the best yields for water and methanolic extraction [22-24]. Most of the available data suggests that alcohols (methanol and ethanol) might be the best solvent for a complete extraction of the flavonoid and polyphenolic molecules synthetized by Teucrium species [9, 22-24, 26]. However, methanolic/dichloromethane extracts from Teucrium species have not been studied previously. Nevertheless, there are more possible factors than solvents that impact the extraction yield, including the dryness, the dimensions of the plant material, temperature, pressure for the processing and the human factor. Taking into account that we started with $2.5 \mathrm{~g}$ of raw material, all the obtained yields are more than satisfactory, implying that the classes of compounds have an intermediate polarity that enables their extraction in methanol.

TFC and TPC determination showed that Teucrium polium was the richest source of natural molecules, followed by T. chamaedris and T. montanum. Moreover, both extracts obtained from $T$. montanum contain the lowest amounts of flavonoids and polyphenols as compared to the other two species. By correlating with available data, $T$. chamaedris and $T$. polium are indicated as important sources of polyphenols and flavonoids, but comparative studies between all three species in terms of their chemical profile are scarce $[9,14,18,20,24,26]$.

The flavonoid and polyphenolic acids from the investigated extracts are indicated in Table II, according to their identification and quantification by UPLCPDA analysis.

According to the obtained data the Teucrium species are rich in flavonoids, both aglycons and glycosylated derivatives. Our samples presented quercetin, luteolin and apigenin derivatives. Higher amounts of rosmarinic acid, caffeic acid and cinnamic acid were also identified. Similar compounds were identified in Teucrium chamaedrys from Serbia, Italy and Romania, $T$. polium from Iran, Tunisia and T. montanum from Serbia [1, 3, $11,14,18,20,22-25]$. In a comprehensive study, Panovska et al. evaluated the chemical profile of three Macedonian endemic Teucrium species ( $T$. chamaedrys, T. polium and T. montanum) [20]. Their results can be correlated to ours, the spectrophoto- 
FARMACIA, 2021, Vol. 69, 5

metric quantification of TFC and PFC and the HPLC identification data indicate $T$. polium as the best resource of the investigated species. Moreover, caffeic acid, rosmarinic acid and luteolin were identified in all three diethyl ether extracts, while apigenin was detected only in $T$. polium. However, the hydrophilic/lipophilic character of the used solvents (diethyl ether, ethyl acetate and n-butanol) is different from ours (methanol, methanol/dichloromethane) which enabled also the extraction of the glycosides. Preliminary studies on Tunisian $T$. polium showed that the methanolic extract was richer in flavonoids and polyphenolic acids than the ethanolic extract [3]. Various iridoid glycosides were identified in Italian T. chamaedrys, but harpagide (for which we used HPLC grade standard) was detected only in $T$. polium and $T$. montanum samples [11].

Table II

The chemical profile of the methanolic and methanolic/dichloromethane extracts from T. chamaedris, T. polium

\begin{tabular}{|c|c|c|c|c|c|c|}
\hline Compound & $T C m$ & TCmd & $T M m$ & TMmd & $T P m$ & TPmd \\
\hline \multicolumn{7}{|c|}{ Flavonoids ( $\mathrm{mg} / \mathrm{g}$ dry extract) } \\
\hline Catechin & 0.4616 & 0.3535 & 0.4637 & 0.4612 & 0.5659 & 0.3944 \\
\hline Epicatechin & 0.6580 & 0.4293 & 0.1630 & 0.1836 & 0.8438 & 0.7432 \\
\hline Rutoside & 0.5001 & 0.3889 & 0.2952 & 0.2948 & 2.0457 & 1.6360 \\
\hline Quercetin-arabinoside & 1.6051 & 1.5062 & 1.9390 & 1.8830 & - & - \\
\hline Luteolin-7-O-glucoside & 2.9680 & 2.8887 & 4.8636 & 1.8366 & 7.4695 & 6.8292 \\
\hline Apigenin-7-glucoside & 2.8884 & 1.8178 & 5.3509 & 5.1602 & 6.4339 & 6.3238 \\
\hline Luteolin & 1.8947 & 1.6245 & 1.1775 & 0.5859 & 3.8395 & 3.4097 \\
\hline Quercetin & 2.9742 & 2.7583 & 1.5785 & 1.5883 & 0.7905 & 0.8090 \\
\hline Apigenin & 1.4934 & 1.2078 & 0.6531 & 0.5755 & 9.5793 & 8.5548 \\
\hline \multicolumn{7}{|c|}{ Polyphenolic acids ( $\mathrm{mg} / \mathrm{g}$ dry extract) } \\
\hline Caffeic acid & 2.1519 & 2.1350 & - & - & 0.4928 & 0.3091 \\
\hline Cinnamic acid & 0.3784 & 0.2453 & 2.0066 & 1.4546 & - & - \\
\hline Rosmarinic acid & 5.8287 & 5.7124 & 1.6185 & 0.9035 & 10.2448 & 9.6789 \\
\hline \multicolumn{7}{|c|}{ Iridoids ( $\mathrm{mg} / \mathrm{g}$ dry extract) } \\
\hline Harpagide & - & - & 0.1846 & 0.1285 & 0.7385 & 0.5952 \\
\hline
\end{tabular}

The antioxidant potential of the investigated extracts is correlated to the chemical composition. The best DPPH radical scavenger was given by the methanolic $T$. polium extract, followed by $T$. chamaedrys and
T. montanum samples. Taking into account the $\mathrm{IC}_{50}$ values, the decreasing order for DPPH radical scavenging activity is $\mathrm{TPm}>\mathrm{TCm}>\mathrm{TPm}>\mathrm{TCmd} \geq \mathrm{TMm}>$ TMmd (Figure 1, Table III).

Table III

Antioxidant potential of the investigating samples: $\mathrm{IC}_{50}$ values for DPPH radical scavenger activity and enzymatic inhibitory effect

\begin{tabular}{|c|c|c|c|c|}
\hline Sample & $\begin{array}{c}\text { DPPH } \\
(\mu \mathrm{g} / \mathrm{mL})\end{array}$ & $\begin{array}{c}\text { LOX } \\
(\mu \mathrm{g} / \mathrm{mL})\end{array}$ & $\begin{array}{c}\text { BuChE } \\
(\mu \mathrm{g} / \mathrm{mL})\end{array}$ & $\begin{array}{c}\text { AChE } \\
(\mu \mathrm{g} / \mathrm{mL})\end{array}$ \\
\hline$T C m$ & $35.72 \pm 0.08$ & $97.38 \pm 3.27$ & $110.71 \pm 0.39$ & $270.30 \pm 1.87$ \\
\hline TCmd & $47.33 \pm 0.11$ & $101.22 \pm 0.26$ & $128.15 \pm 1.26$ & $315.86 \pm 0.65$ \\
\hline$T M m$ & $50.91 \pm 0.21$ & $101.34 \pm 1.85$ & $190.78 \pm 1.03$ & $296.35 \pm 2.37$ \\
\hline TMmd & $64.30 \pm 0.19$ & $131.15 \pm 1.48$ & $227.37 \pm 0.58$ & $345.30 \pm 2.60$ \\
\hline$T P m$ & $20.71 \pm 0.70$ & $60.13 \pm 0.66$ & $121.77 \pm 0.52$ & $212.84 \pm 2.03$ \\
\hline TPmd & $43.45 \pm 0.15$ & $74.94 \pm 0.83$ & $132.78 \pm 1.43$ & $247.37 \pm 0.58$ \\
\hline Quercetin & $7.42 \pm 0.26$ & $17.45 \pm 0.32$ & 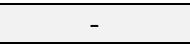 & \\
\hline Galantamine & - & - & $23.20 \pm 0.09$ & $28.70 \pm 0.20$ \\
\hline
\end{tabular}

The activity of enzymes inhibition was also in correlation with the chemical composition and dose dependent, although not for all samples was noted a linear tendency (Figure 1). The relationship between the chemical molecules of polyphenols and the antioxidant activity has been previously investigated. Generally, flavonoids by their chroman ring, hydroxyl moieties and the conjugated double bonds are particularly active against free radicals. Therefore, the obtained extracts that are rich in flavonoid derivatives possess good scavenging effects against DPPH radical.
Also, all extracts exhibited good inhibition against LOX. Taking into consideration the structural differences that influence the solubility of the flavonoids, the richest extracts were obtained in methanol. For this type of extracts obtained from the investigated Teucrium species the activity was higher than for the other type. Their potential may be attributed to the phytocomplex in which flavonoid aglycons and glycosides, as well as the catechins and polyphenolic acids act together to inhibit lipid peroxidation. This aspect was also suggested by various researchers. Due to their chemical 
structure flavonoids may act as powerful chelating and antioxidant agents both in hydrophilic and lipophilic systems, in live organisms or in food. Moreover, quercetin, apigenin and rosmarinic acid, taken as individual molecules have long been recognized as promising antioxidants for therapeutical use [2-5, 8, $11-13,22,27,28]$. Therefore, the chemical complexity of our extracts supports the observed antioxidant effects.

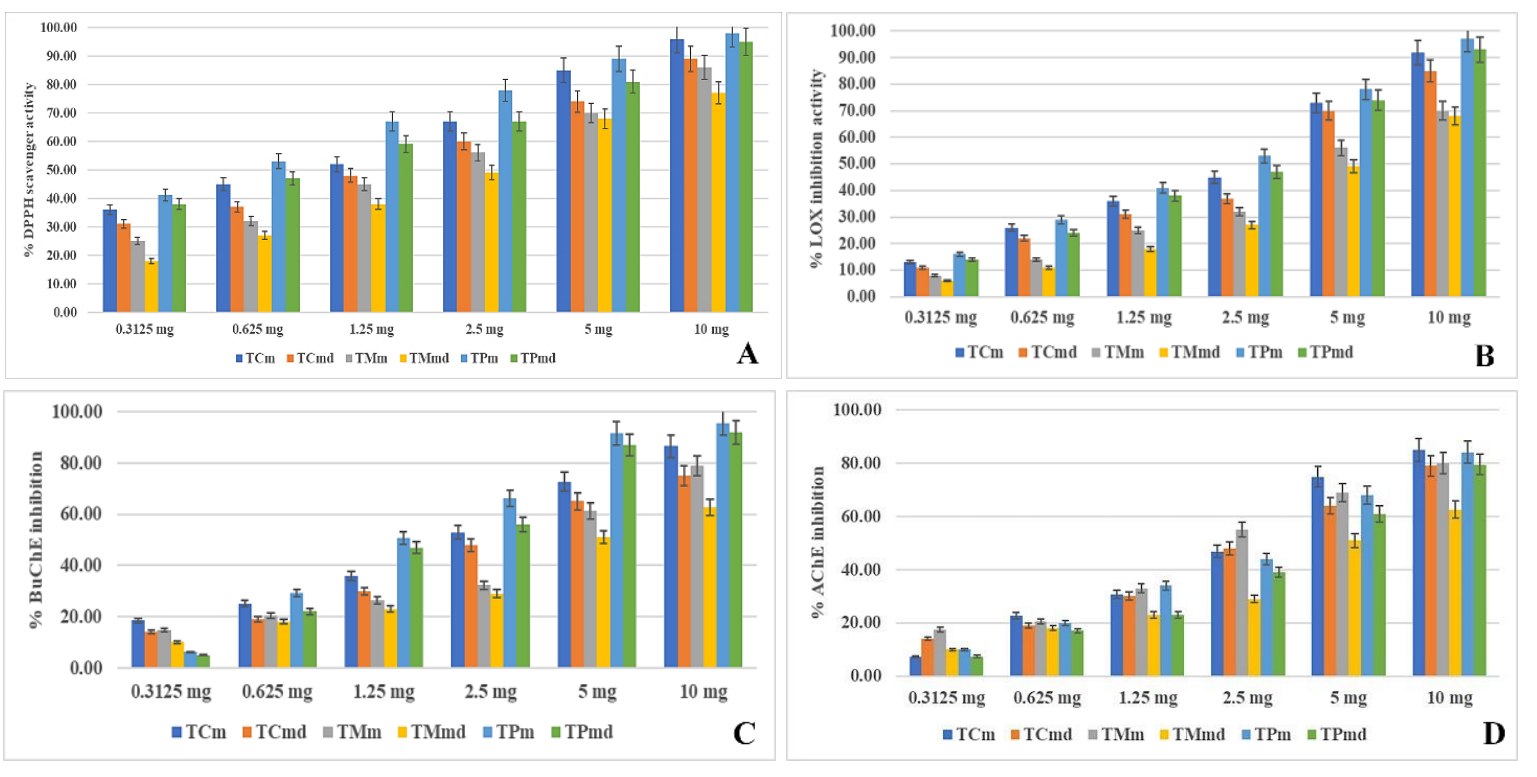

Figure 1.

Antioxidant activity of Teucrium investigated extracts in DPPH (A), LOX (B), BuChE (C) and AChE (D) assay

Regarding the cholinesterase inhibition activity, our samples presented a similar pattern, however, BuChE was stronger inhibited than AChE. Also, the methanolic extracts were more active than the corresponding methanol/dichloromethane extracts. The cholinesterase family belongs to a group of proteins, part of serine esterases, with a common backbone and variations of helical structures that enables these structures to act as adhesion molecule-like, hydrolases or as precursors for some hormones. However, the greatest difference between $\mathrm{AChE}$ and $\mathrm{BuChE}$ is their substrate specificity and selectivity for certain inhibitors. The structures and functions have already been established, AChE coordinating cholinergic transmission in neuronal and muscle tissues, while serum $\mathrm{BuChE}$ may be considered a marker for thyroid, liver and kidney disorders $[6,7$, 9]. Therefore, although the investigated samples were less active than galantamine used as standard, their inhibition potential should be taken into consideration. The registered $\mathrm{IC}_{50}$ values ranged between $110 \mu \mathrm{g} / \mathrm{mL}$ (TCm) and $345 \mu \mathrm{g} / \mathrm{mL}$ (TMmd). Interestingly, the most potent sample was TCm, followed by TPm. The increasing potential of the investigated extracts against BuChE was in the following order: TMmd $<\mathrm{TMm}<$ TPmd $<\mathrm{TCmd}<\mathrm{TPm}<\mathrm{TCm}$. However, the inhibitory effect against $\mathrm{AChE}$ was directly correlated to the chemical composition, all methanolic extracts were more active, the increasing order being different than that for BuChE, TMmd $<$ TCmd $<\mathrm{TMm}<\mathrm{TCm}<$
TPmd < TPm. The best activity against AChE was exhibited by both extracts obtained from $T$. polium.

\section{Conclusions}

Overall, the obtained results indicate that Teucrium species, $T$. polium especially, represent rich sources of bioactive molecules. The polyphenol rich extracts exhibited good antioxidant activity and may represent future reliable resources as natural food additives and food supplements to protect against and inhibit the oxidative processes. However, the exact mechanisms and the possible toxicity needs to be further evaluated for each type of extract to minimize the adverse impact. Nevertheless, this study represents a starting point for Romanian endemic Teucrium species evaluation.

\section{Conflict of interest}

The authors declare no conflict of interest.

\section{References}

1. Bahramikia S, Yazdanparast R, Phytochemistry and medicinal properties of Teucrium polium L. (Lamiaceae). Phytother Res., 2012; 26(11): 1581-1593.

2. Burda S, Oleszek W, Antioxidant and antiradical activities of flavonoids. J Agric Food Chem., 2001; 49(6): 2774-2779.

3. Chioibas R, Susan R, Susan M, Mederle O, Vaduva DB, Radulescu M, Berceanu M, Danciu C, Khaled Z, Draghici G, Marti D, Antimicrobial Activity Exerted 
FARMACIA, 2021, Vol. 69, 5

by Total Extracts of Germander. Rev Chim., 2019; 70(9): 3242-3244.

4. Chouikh A, Phytochemical profile, antioxidant, analgesic and hypolipidaemic effects of Ephedra alata Decne. female cones extract. Farmacia, 2020; 68(6): 10111020.

5. Cioanca O, Mircea C, Hritcu L, Trifan A, Mihasan M, Aprotosoaie AC, Robu S, Gille E, Hancianu M, In vitro-in vivo correlation of the antioxidant capacity of Salviae aetheroleum essential oil. Farmacia, 2015; 63(1): 34-39.

6. Cousin X, Hotelier T, Giles K, Pierre Toutant J, Chatonnet A, aCHEdb: the database system for ESTHER, the $\alpha / \beta$ fold family of proteins and the Cholinesterase gene server. Nucleic Acids Research, 1998; 26(1): 226-228.

7. Danciu C, Cioanca O, Hancianu M, Racoviceanu R, Muntean D, Zupko I, Oprean C, Tatu C, Paunescu V, Proks M, Diaconeasa Z, Botanical Therapeutics (Part II): Antimicrobial and In Vitro Anticancer Activity against MCF7 Human Breast Cancer Cells of Chamomile, Parsley and Celery Alcoholic Extracts. Anti-Cancer Agents in Medicinal Chemistry, 2021; 21(2): 187-200.

8. Dınç M, Doğu S, Koca AD, Kaya B, Anatomical and nutlet differentiation between Teucrium montanum and T. polium from Turkey. Biologia, 2011; 66(3): 448-453.

9. Durrant AR, Tamayev L, Anglister L, Serum cholinesterases are differentially regulated in normal and dystrophin-deficient mutant mice. Front $\mathrm{Mol}$ Neurosci., 2012; 5: 73: 1-10.

10. El Atki Y, Aouam I, Taroq A, Lyoussi B, Taleb M, Abdellaoui A, Total phenolic and flavonoid contents and antioxidant activities of extracts from Teucrium polium growing wild in Morocco. Materials Today: Proceedings, 2019; 13: 777-783.

11. Frezza C, Venditti A, Matrone G, Serafini I, Foddai S, Bianco A, Serafini M, Iridoid glycosides and polyphenolic compounds from Teucrium chamaedrys L. Nat Prod Res., 2018; 32(13): 1583-1589.

12. Godeanu C, Costea T, Ghica M, Lupuliasa D, Gird C, Evidence-based use of sea buckthorn fresh juice for patients with traumatic brain injury. A pilot study. Farmacia, 2020; 68(3): 541-546.

13. Hanganu DA, Benedec DA, Olah NK, Ranga F, Mirel SI, Tiperciuc BR, Oniga I, Research on enzyme inhibition potential and phenolic compounds from Origanum vulgare ssp. vulgare. Farmacia, 2020; 68(6): 1075-1080.

14. Harborne JB, Tomás-Barberán FA, Williams CA, Gil MI, A chemotaxonomic study of flavonoids from European Teucrium species. Phytochemistry, 1986; 25(12): 2811-2816.

15. Humulescu I, Lungu II, Cioancă $\mathrm{O}$, Sava AR, Buciscanu I, Robu S, Toma C, Hăncianu M, Morphological features of Romanian endemic Teucrium L. species. Rev Med Chir Soc Med Nat Iasi, 2020; 124(1): 157-162.

16. Kremer D, Bolarić S, Ballian D, Bogunić F, Stešević D, Karlović K, Kosalec I, Vokurka A, Rodríguez JV, Randić M, Bezić N, Morphological, genetic and phytochemical variation of the endemic Teucrium arduini L. (Lamiaceae). Phytochemistry, 2015; 116: 111-119.

17. Mazhangara IR, Idamokoro EM, Chivandi E, Afolayan AJ, Phytochemical screening and in vitro evaluation of antioxidant and antibacterial activities of Teucrium trifidum crude extracts. Heliyon, 2020; 6(9): e04395: 1-8.

18. Mitreski I, Stanoeva JP, Stefova M, Stefkov G, Kulevanova S, Polyphenols in Representative Teucrium Species in the Flora of R. Macedonia: LC/DAD/ESIMS $^{\mathrm{n}}$ Profile and Content. Nat Prod Comm., 2014; 9(2): $175-180$

19. Păduraru AF, Cioancă O, Mircea C, Trifan A, Aprotosoaie AC, Miron A, Gille E, Hritcu L, Hăncianu M, Bioactive extracts from cultivated Ajuga genevensis $\mathrm{L}$. and A. reptans $\mathrm{L}$.: In vitro/in vivo pharmacological effects. Farmacia, 2020; 67(4): 603-609.

20. Panovska TK, Kulevanova S, Stefova M, In vitro antioxidant activity of some Teucrium species (Lamiaceae). Acta Pharmaceutica, 2005; 55: 207-214.

21. Robu S, Romila A, Buzia OD, Spac AF, Diaconu C, Tutunaru D, Lisa E, Nechita A, Contribution to the optimization of a gas chromatographic method by $\mathrm{QbD}$ approach used for analysis of essential oils from Salvia officinalis. Rev Chim., 2019; 70(6): 2015-2020.

22. Sharififar F, Dehghn-Nudeh G, Mirtajaldini M, Major flavonoids with antioxidant activity from Teucrium polium L. Food Chem., 2009; 112(4): 885-888.

23. Stanković M, Topuzović M, Marković A, Pavlović D, Solujić S, Nićiforović N, Mihailović V, Antioxidant activity, phenol and flavonoid contents of different Teucrium chamaedrys L. exstracts. Biotechnology \& Biotechnological Equipment, 2010; 24(Sup1): 82-86.

24. Stankovic MS, Curcic MG, Zizic JB, Topuzovic MD, Solujic SR, Markovic SD, Teucrium plant species as natural sources of novel anticancer compounds: antiproliferative, proapoptotic and antioxidant properties. Int J Mol Sci., 2011; 12(7): 4190-4205.

25. Vlase L, Benedec D, Hanganu D, Damian G, Csillag I, Sevastre B, Mot AC, Silaghi-Dumitrescu R, Tilea I, Evaluation of antioxidant and antimicrobial activities and phenolic profile for Hyssopus officinalis, Ocimum basilicum and Teucrium chamaedrys. Molecules, 2014; 19(5): 5490-5507.

26. Zlatić NM, Stanković MS, Simić ZS, Secondary metabolites and metal content dynamics in Teucrium montanum L. and Teucrium chamaedrys L. from habitats with serpentine and calcareous substrate. Environ Monit Assess., 2017; 189(3): 110: 1-15.

27. Marinescu E, Elisei AM, Aprotosoaie AC, Cioanca O, Trifan A, Miron A, Robu S, Ifrim C, Hancianu $\mathrm{M}$, Assessment of heavy metals content in some medicinal plants and spices commonly used in Romania. Farmacia, 2020; 68(6):1099-1105.

28. Lisa EL, Carac G, Barbu V, Robu SI, The synergistic antioxidant effect and antimicrobial efficacity of propolis, myrrh and chlorhexidine as beneficial toothpaste components. Rev ChimBuchar., 2017; 68: 2060-2065. 